\title{
Thermal response to cold in buildings with green covers for tropical climate. Green facades and green roofs
} Reacción frente al frío de edificaciones con envolventes
vegetalles para climas tropicales. Fachadas verdes y cubiertas
ajardinadas

\author{
N. Pérez Gallardo ${ }^{*}$, A. Rogério*, G. Figueiredo Neves*, F. Arthur Vecchia*, V. Figueiredo Roriz** \\ * Universidad de São Paulo, São Paulo. BRASIL \\ ** Universidad Dom Pedro II. Rua Badi Bassiti, São José do Rio Preto. BRASIL
}

Fecha de Recepción: 02/08/2017

Fecha de Aceptación: 12/12/2017

\section{Abstract}

PAG 15-28

\begin{abstract}
The main aim of this paper is to demonstrate the benefits that building using natural elements can provide to indoor environments when temperatures are lower. For this purpose, an experimental procedure was used to allow a comparison of the thermal behaviour of four systems: a prototype called Control (no vegetation) and three different combinations of vegetation (roofs and facades) installed in a region of tropical climate. They recorded simultaneously internal surface temperatures, internal air temperature and the external environmental conditions. The results show that the use of plant systems in buildings establishes a passive technique effective in reducing energy consumption, because of its insulation property and it maintains more pleasant thermal internal conditions than internal ones.
\end{abstract}

Keywords: Green facades, green roof, thermal performance, thermal comfort, bioclimatic architecture

Resumen

El objetivo de este trabajo es demostrar los beneficios que los sistemas constructivos con envolventes vegetales pueden ofrecer a los ambientes internos cuando las temperaturas son más bajas. Para ello, se ha utilizado un procedimiento experimental que permite la comparación del comportamiento térmico de cuatro sistemas: un prototipo Ilamado Control (sin vegetación) y tres con diferentes combinaciones de vegetación (cubiertas y fachadas) construidos en una región de clima tropical. Se registraron simultáneamente las temperaturas de las superficies internas, las temperaturas del aire interno y las condiciones del ambiente externo. Los resultados obtenidos demuestran que el uso de sistemas vegetales en la edificación constituye una técnica pasiva efectiva en la reducción del consumo de energía debido a su capacidad tanto de aislamiento térmico como de conservación de unas condiciones internas más agradables.

Palabras clave: Fachadas verdes, techos verdes, comportamiento térmico, confort térmico, arquitectura bioclimática

\section{Introduction}

Due to the population increase and the growth in urban centres, there have been significant environmental impacts as a result of the massive concentration of buildings, causing the sealing of soil, reduction of green spaces and air pollution increment. All this leads to, a thermal behaviour modification microclimate scale and generates what is called Urban Heat Island (Vecchia, 2005).

The gradual concern about these issues has led to a greater interest for a more sustainable architecture. Green spaces inside cities can be considered as environmental quality indicators. The use of vegetation on roofs and facades is a technique which has a positive impact on urban climate, due to the characteristics of the plants that create shaded areas, absorb some of the incident radiation, and encourage rainwater infiltration; therefore, they also increase the relative humidity, all the factors that contribute to Heat Urban Island.

\footnotetext{
1 Corresponding author:

Universidad de São Paulo, São Paulo. Brasil

E-mail: nuriapg@sC.usp.br
}

According to (Dunnett and Kingsbury, 2008), the vegetation is a technique that has been used for centuries throughout the world to improve the thermal comfort in buildings. This is one of the reasons why the technique is being accepted with a great interest nowadays, in addition to the environmental benefits which are offered, it improves the internal thermal comfort and thus the energy efficiency of buildings. The use of Green Facades with climbing plants is able to reduce the internal temperature of buildings due to the shading that occurs there. Also, in winter, this system protects from the cold and wind, by the branched structure forming by the stem of the plant, avoiding losses of internal heat.

This paper proposed the study of Green Facades and Green Roofs in a tropical climate for a critical cold day, showing experimental results of four test cells in which were measured internal surface temperatures and internal air temperatures to make subsequently, a comparative study between those test cells with and without vegetation test cell. With the final results, it has been verified the potential vegetation respecting to internal heat losses, since, such reduction of heat losses is one of the most useful measures in the sense of improving indoor comfort conditions. 


\section{Materials and methods}

This Project about plant covers in architecture aims the use of construction methods that cause a less impact than conventional buildings, and improve the comfort of indoor environmental energy efficiency. For estimation, four experimental cells were planted vegetation in facades ( $N$ and
$W)$, as well as were installed plants on the roof, as shown in Table 1.

Internal surface temperatures data (IST) and Dry Bulb temperature (DBT) were measured by through thermocouples installed in the test cells. The data of solar radiation and other climatic variables were recorded by the automatic weather station of the Centre of Hydric Resources and Environmental Studies (CRHEA) belonging to the Engineering School of São Carlos (EESC-USP).

Table 1. Summary of test cells types used

\begin{tabular}{|l|l|}
\hline CONSTRUCTION & LOCATION OF VEGETATION \\
\hline Control Cell Test & Without vegetation. \\
\hline Cell Test 1 & Green facades $(\mathrm{N} \& W)$ \\
\hline Cell Test 2 & Green Roof \\
\hline Cell Test 3 & Green Roof + Green facades $(\mathrm{N} \& W)$ \\
\hline
\end{tabular}

To obtain the results, this study was based on the analysis of a critical cold day (winter day), it is defined as a day which was registered, as an exceptional climate form, a minimum temperature lower than the absolute maximum temperatures in the historical data series registered in Normal Climatological 1961-1990, both published in 1992 by the Ministry of Agriculture and Agrarian reform, National Department of Meteorology, Brasilia.

The data were measured by thermocouples installed on the facades North, West and roofs of the four test cells for the period from 07 to 12 July 2015.

\subsection{Localization and characterization of the study area}

This Project was developed in Itirapina- SP in the margins of the Lobo reservoir, at $733 \mathrm{~m}$ altitude above sea level (Figure 1). It is a complex area to define because of the climatic origin actions, being a region in transition from polar and inter-tropical atmospheric systems. It is located in an area considered tropical altitude. According to the International Classification of Köppen correspond with a climate Cwa, which is characterized as a warm climate with dry winters in which the average temperature of the coldest month is less $\tan 18^{\circ} \mathrm{C}$ and the hottest month exceeds $22^{\circ} \mathrm{C}$ (Ferrari, 2012) (Figure 1).

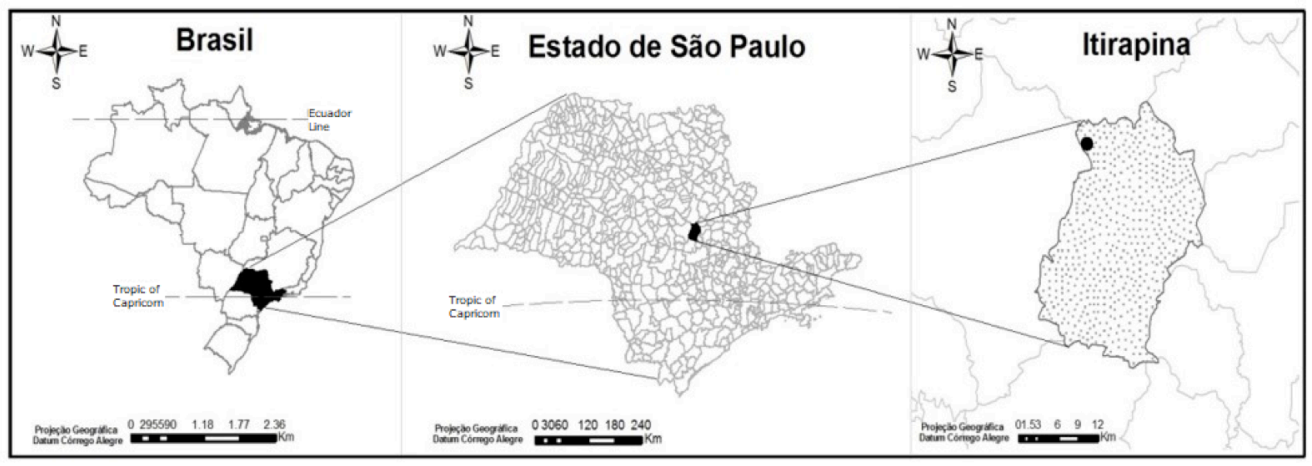

Figure 1. Location of the study area. Source: Own composition 
Test cells' dimensions are $2 \times 2.50 m$, seated on cement mortar and sand built in situ, they are solid brick constructions with dimensions of $10 \times 20 \times 5 \mathrm{~cm}$, placed with joints of $1.5 \mathrm{~cm}$ of thickness. They have a wooden door with eastern orientation whose dimensions are $2.10 \times 0.60 \mathrm{~m}$ and a wooden window facing North with standard measurements of
$1 \times 0.70 m$ (Figure 2). The test cells were designed with the same orientation, so that they receive equal solar radiation, wind and other atmospheric events. This allows the climatic conditions to act simultaneously and at the same intensity in each cell, as shown Figure 2. Also, they do not create shadow zones among them.

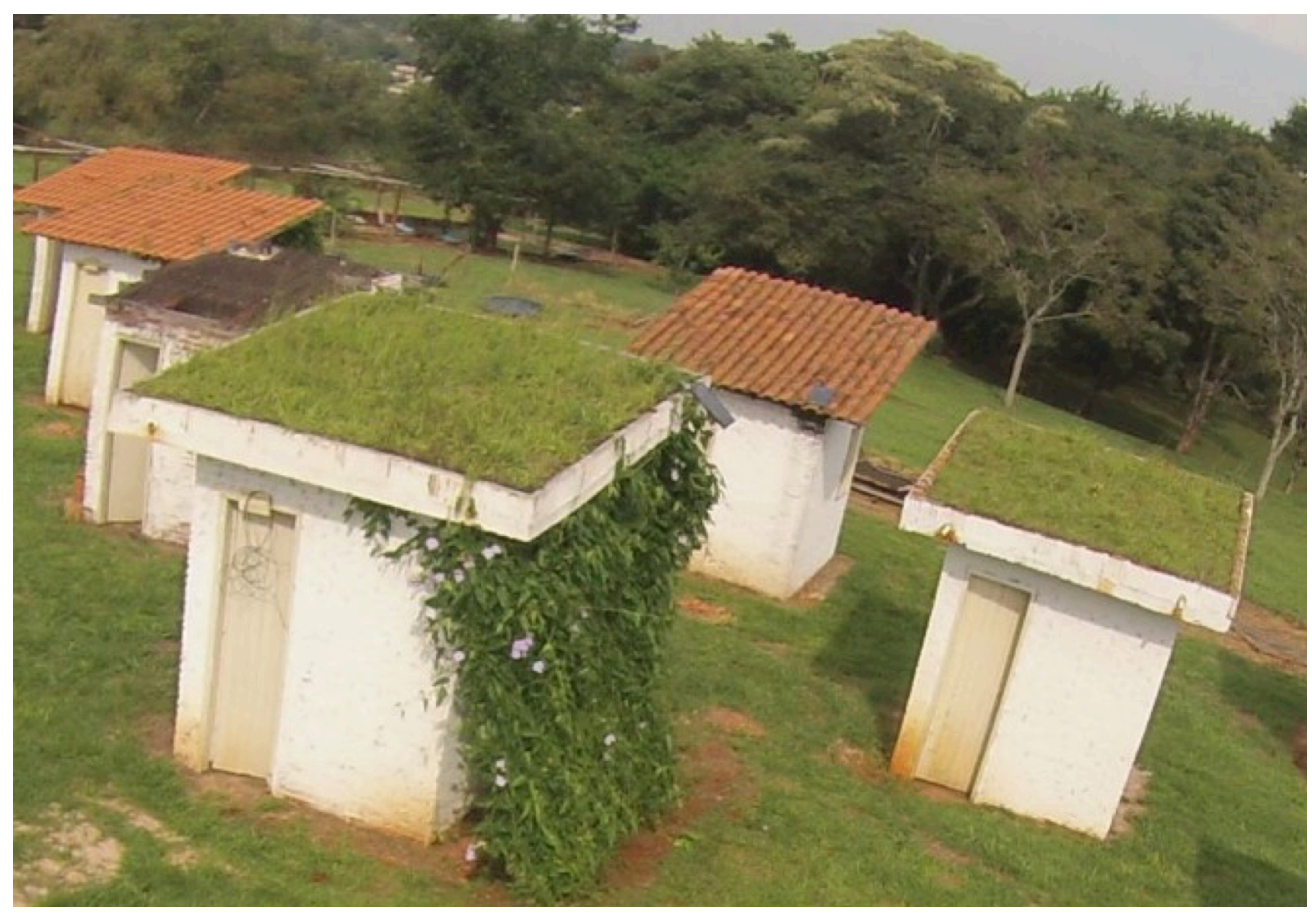

Figure 2. Panoramic experimental cells. Source: Own Composition

\subsection{Construction system and development of green facades and green roofs.}

Green facades were installed in the North and West facades because they are those that receive more sunlight hours. They consist, basically, of a metal hexagonal mesh of $2.40 \mathrm{~m}$ wide by $3 \mathrm{~m}$ high, and anchor to the ground and facades by hooks. The solution adopted was one that did not maintain direct contact with the wall, so it was decided to set up it at an angle of $30^{\circ}$ to the top of the wall.

After placing the necessary mesh to enable upward growth of the plants, and cover the entire surface of the facades, a Thumbergia Grandiflora, part of the Acanthaceas's family was sown at the bottom of the mesh, directly on the ground. This plant is a great low-maintenance vine from tropical and subtropical areas of the world. It is herbaceous and includes within Acanthaceae's family, twining, dark green and simple, opposite and whole green leaves. The Thunbergiagrandiflora, is commonly known as blue Tumbergia (Figure 3A) and (Figure 3B), blue trumpet vine, blue Bignonia (Martínez et al., 2002). 


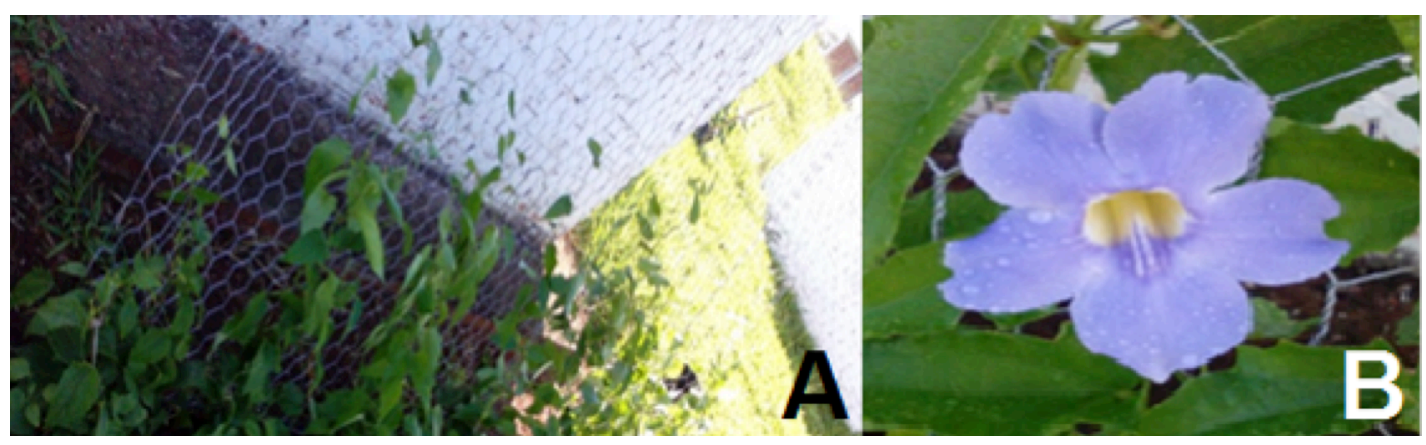

Figure 3. A. Plants growth on wire mesh $B$. Thunbergia grandiflora's flower detail

Source: Own composition

Plant's annual cycle and their growth are two important components to ensure the role of plant facades. Despite the consequences of working with living beings, plants are still in fairly constant cycles in relation to development. However, these guidelines are species-specific and depend on the climate in which the plant is located (Pérez, 2010). (Figure 4)

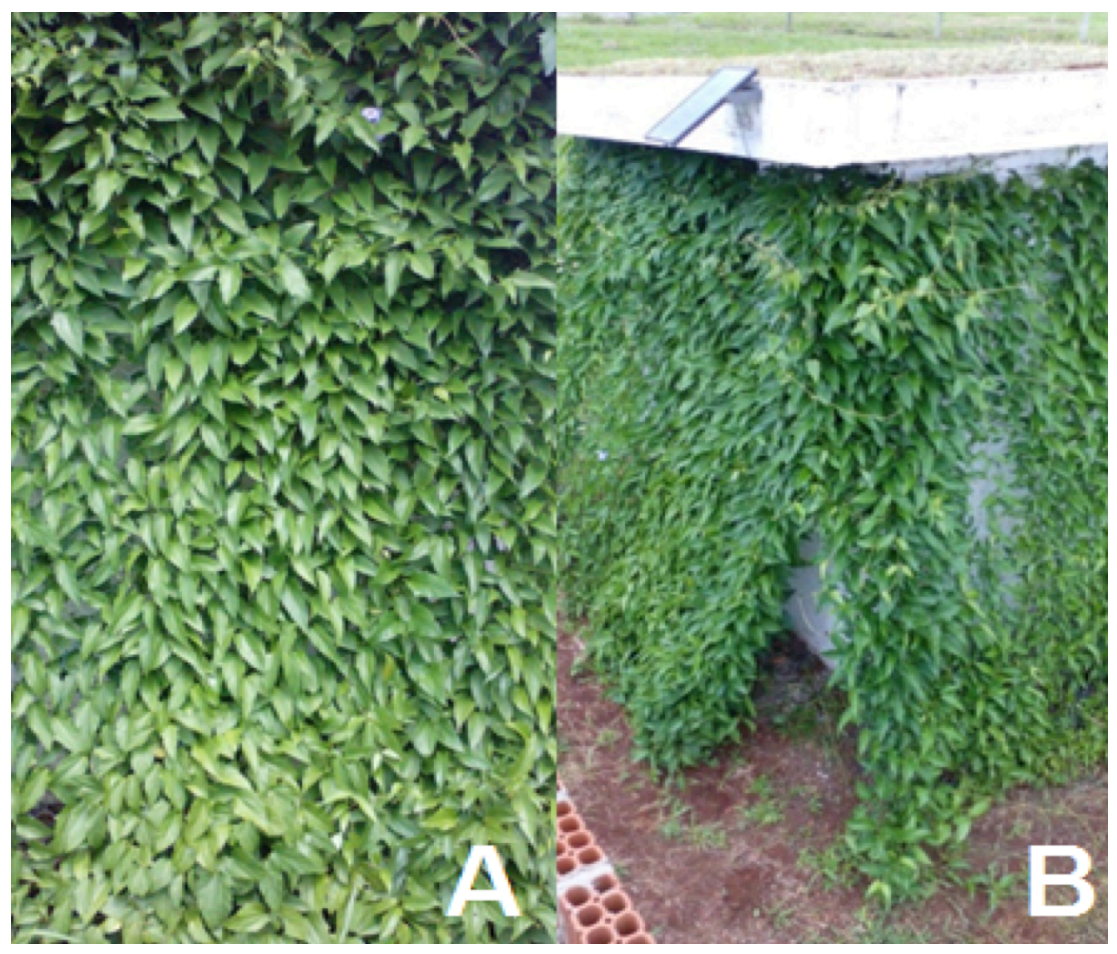

Figure 4. Green facades detail. (A\& B). Source: Own composition

The Green roofs were concreted in situ by a preformed ceramic slab with preformed concrete beams with an inclination of $23 \%$ and parapets of ceramic brick with size of $0.40 \mathrm{~m}$, to form a drawer where the substrate is settled. As it is shown in the figure, the set of the Green roofs are composed by a waterproof layer, a drainage blanket, substrate and vegetation, as shown in Figure 5 and Figure 6. 


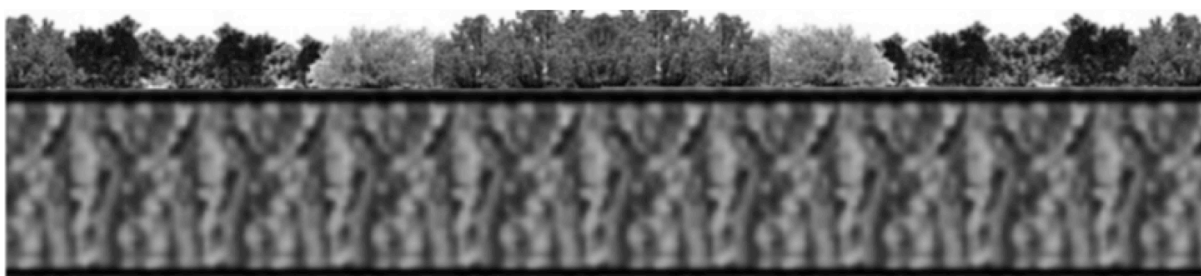

Vegetation (Grass)
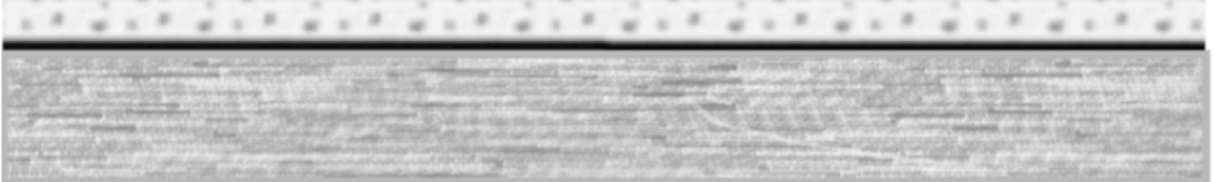

Drainage blanket

Waterproof layer

Support structure

(slab)

Figure 5. Profile of Green roof. Source: Own composition

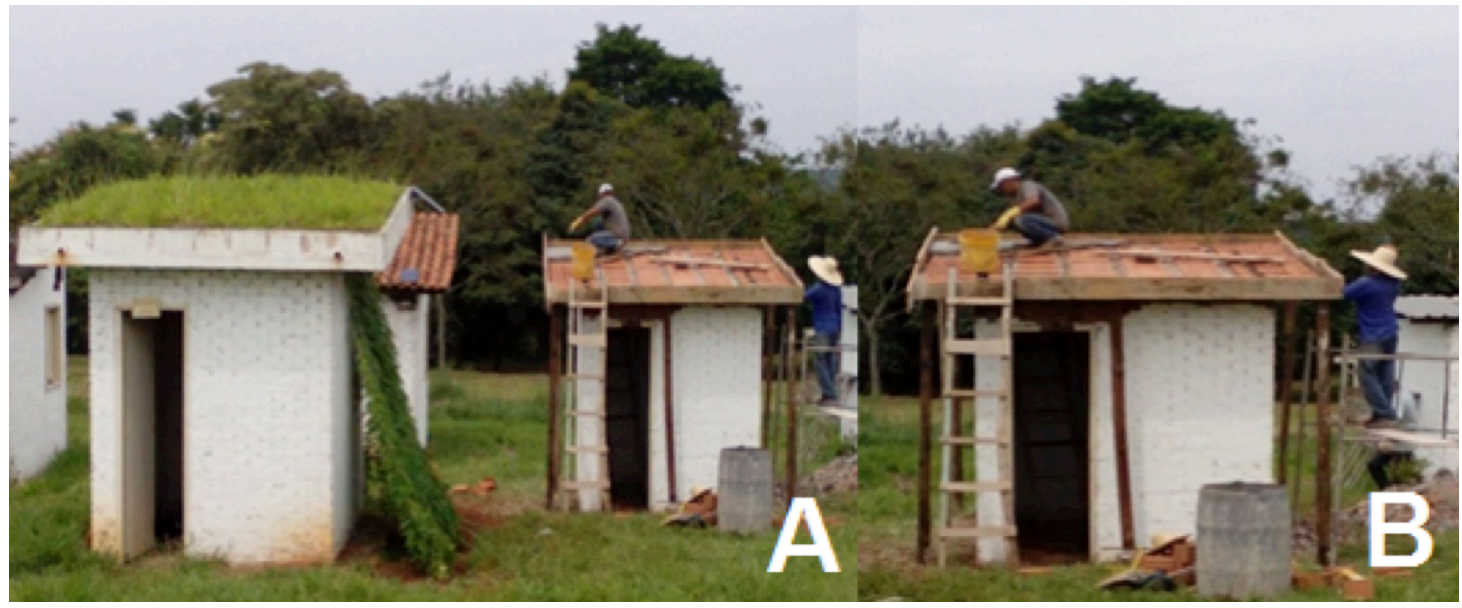

Figure 6. Green roofs construction (A) \& (B). Source: Own composition system:

Below it will be described each item that makes up the

\section{- Geosynthetic and drainage:}

The drainage element used was a geosynthetic blanket MacDrain 2L used for drainage of highways and other civil works, it is a mild and flexible feature whose draining core consists of a tridimensional geomat, composed by filaments of polypropylene, with a thickness between 10 and $18 \mathrm{~mm}$, heat sealed among two geotextiles with polyester resin based at all contact points (Vecchia, 2005). For drainage two PVC tubes were placed in lower ends.
- Vegetation. grass:

Paspalumnotatum grass was used as vegetation to cover the Green roofs (Figure 6), which is a native grass of the American continent, it is known in Brazil as the Batataisgrama, grass-forquilha, grama-mato-grosso, grama-depasto and grass-Common (Lorenzi and Souza, 2000) It has leaves concentrated on the basal part of the plant. One of the outstanding properties is the facility to cover easily the ground, forming large mats, and this is the reason why it is used in football fields and green areas, including protection against soil erosion (Kissmann, 1997). It is a species able to adapt to poor soils, water deficit conditions, resistant to the action of sunlight and treading. Although it needs to be cut frequently to maintain good quality (Goatley et al., 1998) (Figure 7). 


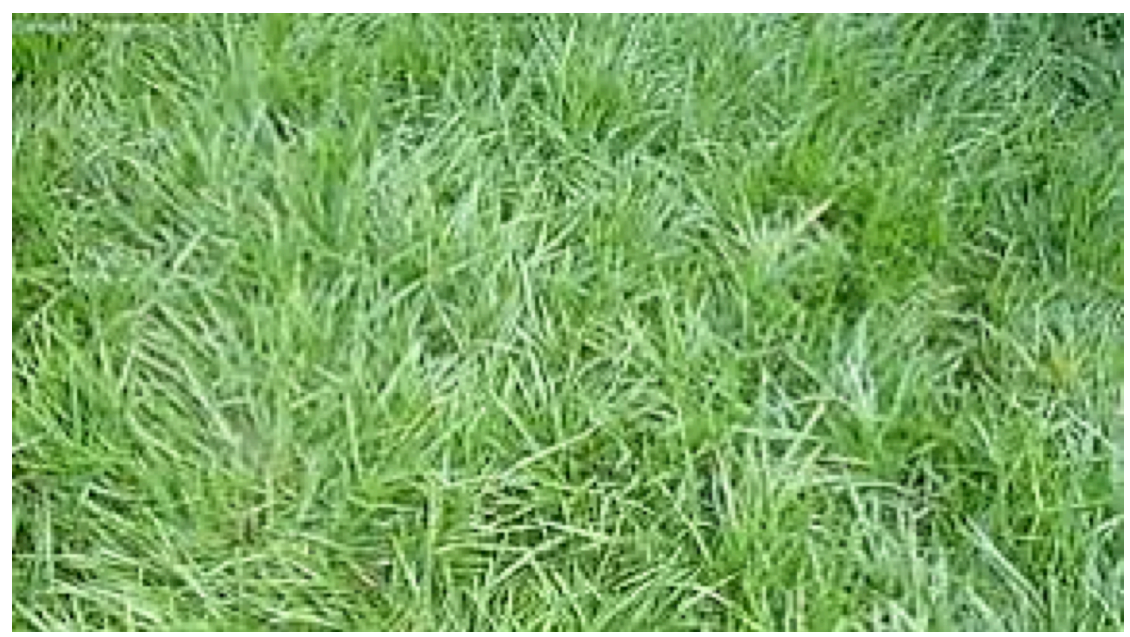

Figure 7. Detail grass. Grama Batatais -forquilha species. Source: Own composition.

Automatic measurements

Each of the prototypes is made up of 15 T-type thermocouples $2 \times 24$ WG. Thermocouples are characterized as a very precise instrument. The temperature can be measured with an error of $\pm 0.1-0.2{ }^{\circ} \mathrm{C}$ (Kinzie, 1973). The measurements were used to study the thermal behaviour. For this reason, there were located 64 thermocouples, 16 per constructive elements, 15 (for each test cell) measuring surface temperatures and a thermocouple was placed at the geometric centre of each test cell at a height of $1.20 \mathrm{~m}$ approximately, to carry out measurements of the Dry Bulb
Temperature (DBT), as the ABNT NBR 15575-1 Standard referred to in Annex $A$.

The data register was set at intervals of 30 seconds and they are totalled measured every hour. The measures are recorded by a programmable data logger CR1000, Campbell Scientific Inc., connected with two 32-channel multiplexers 416AM Campbell Scientific Inc, which are both currently calibrated. The battery is fed by a solar panel which gives autonomy to the equipment. distribution.

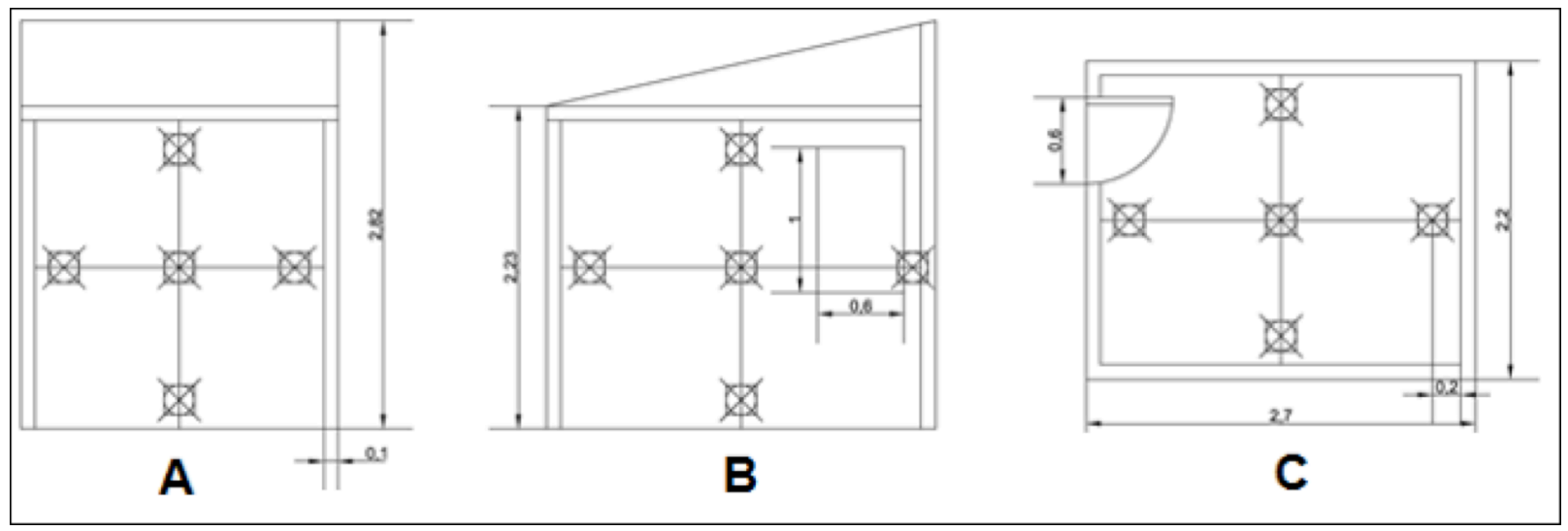

Figure 8. Distribution of thermocouple type $T$ (Copper-Constantan).A-In West facades. B-In North facades. C-In roofs. Source: Own composition (Unscaled) 


\section{Experimental resullts and analysis}

\subsection{Climate analysis. critical experimental cold day, July 10, 2015}

Under the climate perspective used in this work, the experimental critical Day was defined considering dominant atmospheric state in the testing period. It was used as a reference by the Normal Climatological 1961-1990 which was published in 1992 by the Ministry of Agriculture and Agrarian Reform, National Department of Meteorology (historical series of climatic data from Brazil).

According to (Vecchia, 1997), to do a more accurate climate estimation, it can make a climate analysis using representative episodes or observation periods of clime types, that is, studying the intensity and duration of each air mass which dominates on a particular place, related to the atmospheric circulation's phenomena. The consequences of the advance of a cold front over a given locality have peculiar characteristics on each analysed season (Autumn, Winter,...). From a point of view of the dynamic climatology, Itirapina is characterized as a region of passage of cold fronts pass throughout a year. The domain of the acting masses in the region can be divided into two main stages, Prefrontal and postfrontal, which are at the same time subdivided into two other stages, harbinger and advance, which happen before the penetration of the mass Polar Atlantic (MPA) with war features. Afterwards there will occur domain and transition phases, where the Polar Atlantic mass (MPA) imposes weather conditions with a cold feature and sometimes a wet feature (Monteiro, 1967).

This classification which is beneficial because, according to the requirement of analysis climate facing thermal behaviour, can determinate the most appropriate stage to conduct experiments (Vecchia, 2015).Data from external climatic variables used in this experiment from the day in question, were collected by the Climate Station of the Centre for Water Resources and Environmental Studies (CRHEA) of the School of Engineering of Sao Carlos (EESCUSP).

In this study case, the episode from 7 to 12 July 2015, was considered for analysis, days when the Northwest region of the state of São Paulo was under the control of a mass of cold air. In the Figure 9 is shown a climatic analysis of the selected day.

Analysing the climate conditions in the month of July, it is observed a day that can be considered a critical experimental cold day (07/10/2015) because on that day was recorded, as a form of climate exceptionality, a value of solar radiation of $614(\mathrm{~W} / \mathrm{m} 2)$ and a minimum hourly temperature of $8.8^{\circ} \mathrm{C}$, less than the absolute minimum temperature of the Series History $\left(12.1^{\circ} \mathrm{C}\right)$ for that period.

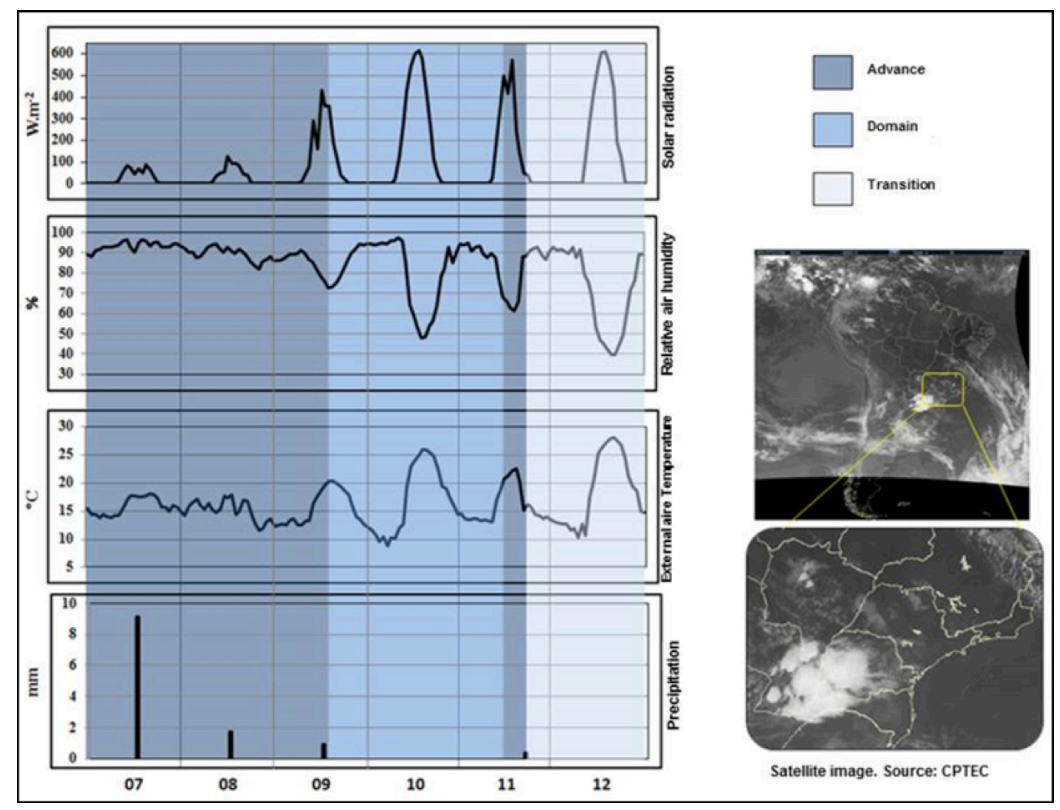

Figure 9. Climate Analysis. Episode 7-12 July 2015. Source: Own author 
3.2 Internal temperatures results in critical experimental cold day: $10 / 07 / 2015$

As it was indicated in the previous section, the experimental data of this work, concerning the winter situation, were recorded on the day July 10, 2015.

\subsubsection{Internal air temperature or dry bulb Temperature (DBT):}

In Figure 10, the graph shows the internal air temperature $(D B T)$, the external air temperature and thermal comfort limits.

The effect expected of an environment with vegetation would be a drop in temperature, which could extend the discomfort for cold, especially in an episode as it is presented on 10 July 2015. However, despite the shading of the building and the effect of air humidification, as shown in Figure 12, the alterations observed are predominant in the period of maximum temperatures, and always in the sense of minimizing the discomfort.

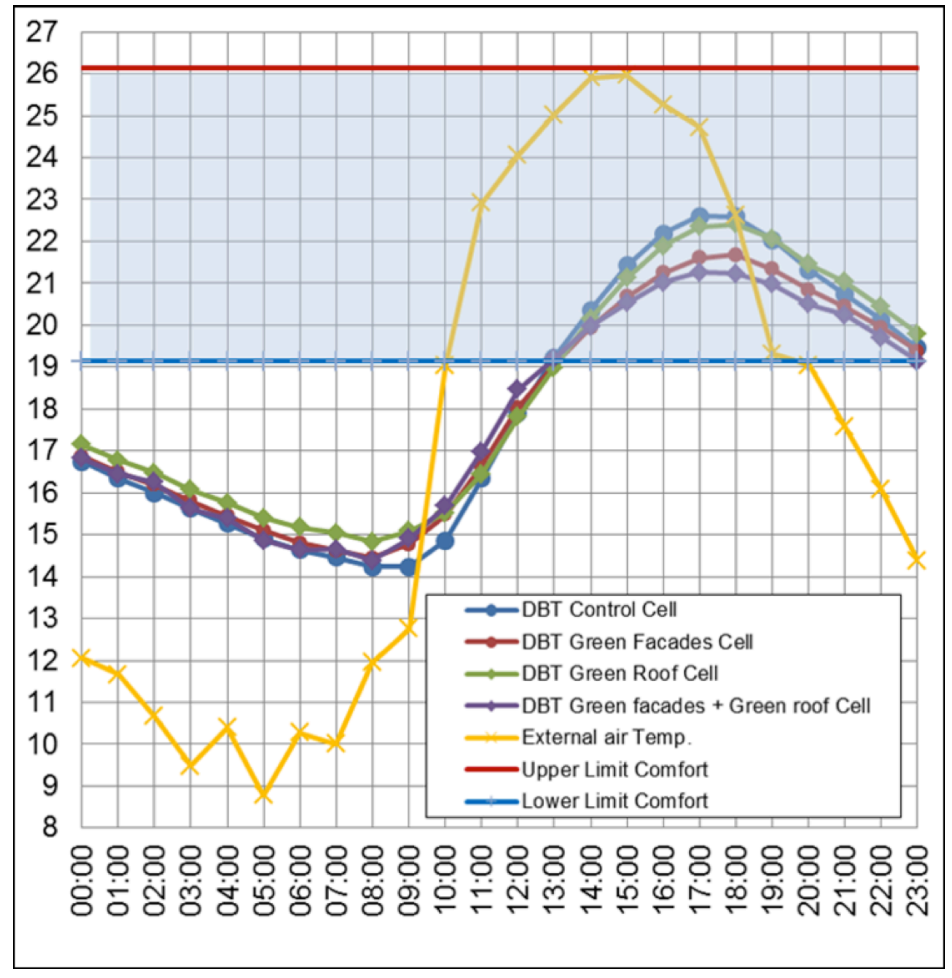

Figure 10. Evolution of internal air temperatures. Source: Own Composition

In addition, it was achieved a quantification of degrees/hours of discomfort as of the adaptive method indicated by (ASHRAE 55, 2013). This methodology sets the limits of comfort for each day of the year, either for $80 \%$ and $90 \%$ of people satisfied in naturally ventilated buildings. To quantify the degrees/hours of discomfort it was necessary to compare hours hourly, the temperature limits (upper and lower) and the operating temperature registered in each of the test cells.

Degrees/hours of discomfort are generated when the internal temperature exceeds the limits set by the standard, (Figure 11) being positive numbers for heat and negative numbers for cold, as shown in the following chart.

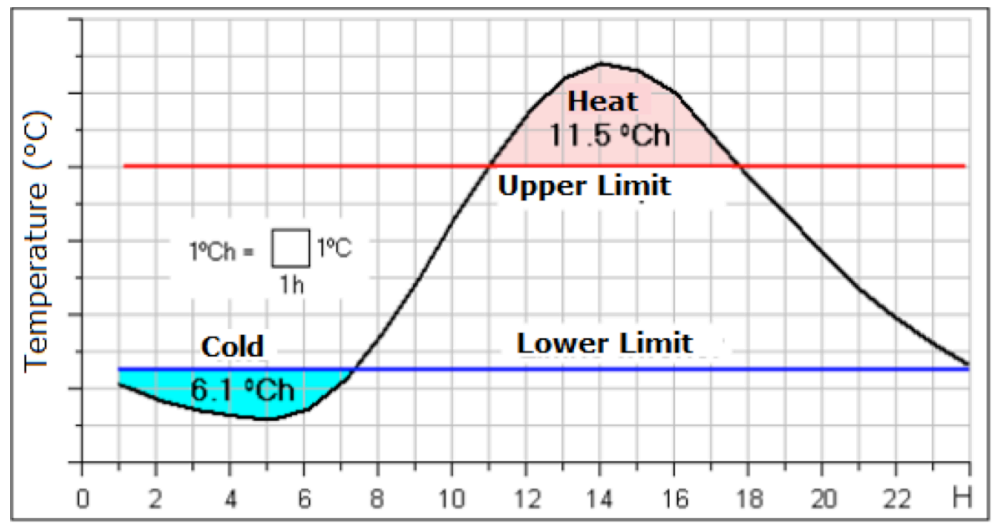

Figure 11. Degrees/hours of discomfort. Source: (Roriz et al., 2009) 
Comfort limits were obtained from the following equation (ASHRAE, 2013).

Upper Limit $80 \%$ satisfied $=0.31 t_{\text {pma(out })}+21.3=26.14^{\circ} \mathrm{C}$

Lower limit $80 \%$ satisfied $=0.31+\mathrm{t}_{\mathrm{pma} \text { (out) }} 14.3=19.14^{\circ} \mathrm{C}$

Where, $t_{\text {pma(out) }}$ corresponds to the central temperature in the range of comfort, calculated as average of the temperatures of the last 15 days, assuming in this case the value of $15.6^{\circ} \mathrm{C}$.

In Table 2, it is showed the calculation result of hours for discomfort. It is not recorded any hour for heat discomfort, however, it is observed several degrees / hour of discomfort by cold, the maximum value $\left(47^{\circ} \mathrm{C} / \mathrm{h}\right)$ is recorded in the control test cell and the minimum value $\left(41.41^{\circ} \mathrm{C} / \mathrm{h}\right)$ in the cell which Green Roof, followed by the test cell with Green Facades and Green Rood $\left(43.69^{\circ} \mathrm{C} / \mathrm{h}\right)$.

In this day and as it shown in Figure 10, it is observed that in the morning period, in the early hours of the day, the four test cells follow the same behaviour. At the time when the lower external air temperature $\left(8.78^{\circ} \mathrm{C}\right.$ at $\left.5 \mathrm{~h}\right)$ is recorded, it can be viewed that the minimum internal temperatures $\left(15^{\circ} \mathrm{C}\right)$ are registered in the cell with Green Facade, Control Cell, and the cell with Green Roof.

By contrast, at the same hour, higher air temperature is recorded in the cell with Green Roof $\left(15,4^{\circ} \mathrm{C}\right)$. In addition, it is noted that since the minimum external temperature is registered until the minimum internal air temperature is recorded, there is a thermal delay of 4 hours, as the minimum internal temperatures recorded happened at $9 \mathrm{~h}$.

Table 2. Degree/Hours Discomfort

\begin{tabular}{|l|l|l||}
\hline \multicolumn{2}{|l||}{ DEGRES/ HOURS OF DISCOMFORT DAY JULY 07, 2015 } \\
\hline CASES & HEAT & COLD \\
\hline DBT Control Cell & 0.00 & -47.26 \\
\hline DBT Green Facades Cell & 0.00 & -44.19 \\
\hline DBT Green Roof Cell & 0.00 & -41.41 \\
\hline DBT Green Facades + Green Roof Cell & 0.00 & -43.69 \\
\hline
\end{tabular}

The difference between internal air temperatures in the evening period is not excessive, since, according to the data, we can see that the higher difference between internal air temperatures of the 4 cells (just $2^{\circ} \mathrm{C}$ ) is between the test cell built with conventional materials $\left(22.6^{\circ} \mathrm{C}\right.$ at $\left.18 \mathrm{pm}\right)$ and the cell endowed with Green Facades and Green Roof $\left(21.2^{\circ} \mathrm{C}\right.$ at $\left.18 p m\right)$.
The behaviour of the internal air temperature's curves when the maximum external temperature is registered $\left(25.9^{\circ} \mathrm{C}\right.$ at $14 \mathrm{~h})$, shows that there is a thermal delay behind internal air temperatures recorded $4 \mathrm{~h}$. Next table exposes the external temperature amplitude of $17^{\circ} \mathrm{C}$, while that, in the indoor environments is about $7^{\circ} \mathrm{C}$ for all the test cells studied. See Table 3.

Table 3. Summary of temperature variation in the internal air temperatures

\begin{tabular}{|l|l|l|l|l|}
\hline $\begin{array}{l}\text { INTERNAL AIR } \\
\text { TEMPERATURE }\end{array}$ & $\begin{array}{l}\text { DBT }\left({ }^{\circ} \mathrm{C}\right) \\
\text { Control } \\
\text { Cell }\end{array}$ & $\begin{array}{l}\text { DBT }\left({ }^{\circ} \mathrm{C}\right) \text { Green } \\
\text { Facades Cell }\end{array}$ & $\begin{array}{l}\text { DBT }\left({ }^{\circ} \mathrm{C}\right) \text { Green } \\
\text { Roof Cell }\end{array}$ & $\begin{array}{l}\text { DBT }\left({ }^{\circ} \mathrm{C}\right) \text { Green } \\
\text { Facades+ Green Roof } \\
\text { Cell }\end{array}$ \\
\hline$T^{\circ} \mathrm{C}$ Min. & 14,23 & 14,4 & 14,84 & 14,39 \\
\hline$T^{\circ} \mathrm{C}$ Max. & 22,61 & 21,67 & 21,41 & 21,26 \\
\hline$\Delta T^{\circ} \mathrm{C}$. & 8,38 & 7,27 & 6,57 & 6,87 \\
\hline
\end{tabular}




\subsubsection{Internal surface temperature's north facades}

Internal surface temperatures (IST) of North facades, as shown in Figure 12, in the early morning when the minimum external temperatures are recorded, presents a difference between recorded values in cells tested about $1{ }^{\circ} \mathrm{C}$ and $6^{\circ} \mathrm{C}$ regarding external temperature.

When the external temperature starts to rise, the behaviour of the test cells begins to differentiate, recording in the control cell maximum measure of temperature in the internal surface of the North Facades with maximum internal surface temperature of $25^{\circ} \mathrm{C}$ at $17 \mathrm{~h}$. Moreover, it was registered the maximum internal surface temperature, $24,1^{\circ} \mathrm{C}$ at $17 \mathrm{~h}$, in the cell constructed with Green roof. That is, both have a thermal delay respect to the external air temperature $\left(25.97^{\circ} \mathrm{C}\right.$ at $\left.15 \mathrm{~h}\right)$ of 2 hours.

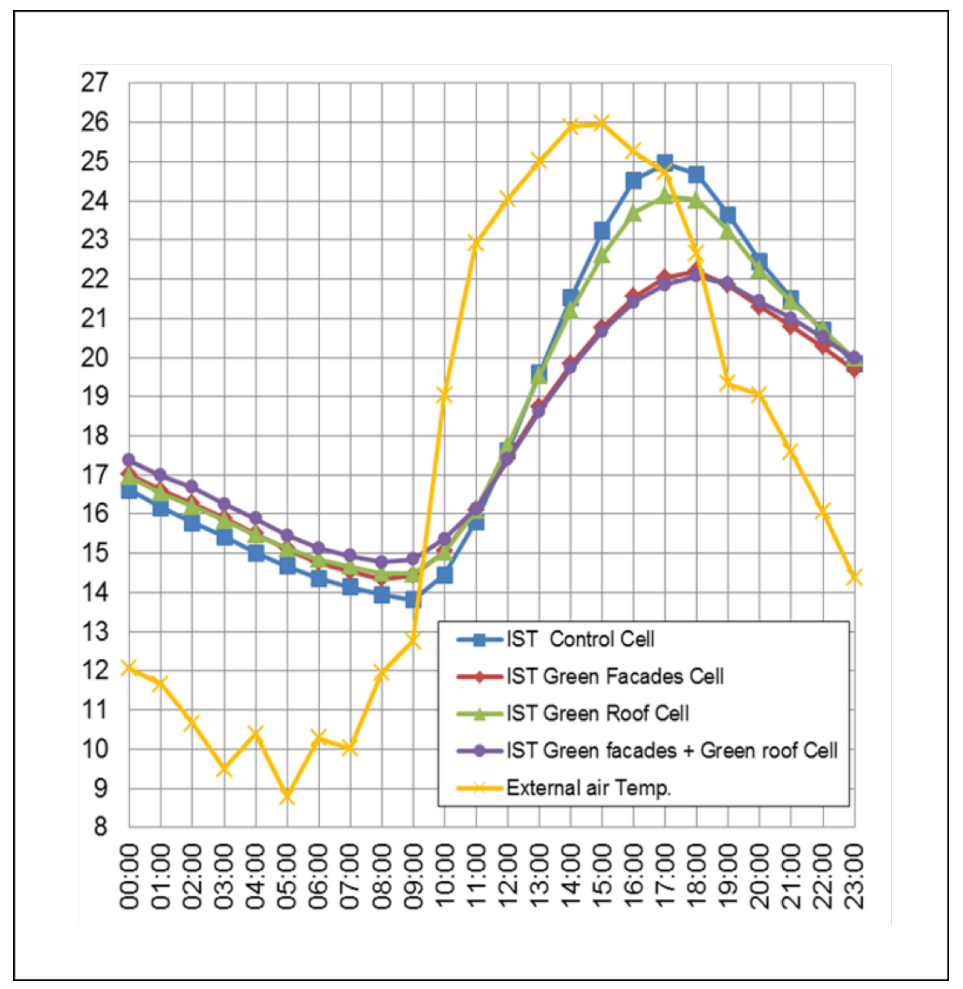

Figure 12. Internal surface temperature's north facades vs. external air temperature: Graphic. Source: Own author

At 18h, minimum surface temperatures in the North facades were recorded in two cells which facades were built with vegetation, that is, the cell with the cell Green Facades and the cell with Green facades and Green Roof. The value of the temperature was $22^{\circ} \mathrm{C}$, that is, $2^{\circ} \mathrm{C}$ less than temperatures facades devoid of vegetation in North Facades (conventional materials cell and Green Roof cell). Moreover, the difference respect the maximum external temperature is $4^{\circ} \mathrm{C}$.
Give that for an external thermal amplitude of $17^{\circ} \mathrm{C}$, it is observed an internal thermal amplitude of $7^{\circ} \mathrm{C}$ for cells with vegetation on its northern facade, and a thermal amplitude of $11^{\circ} \mathrm{C}$ for cells with solid ceramic brick facades, it can be stated that Green facades have a better behaviour with respect to the internal surface temperature, which was built with brick facades (Table 4).

Table 4. Thermal amplitudes in north facades. Source: author

\begin{tabular}{|l|l|l|l|l||}
\hline NORTH FACADES & $\begin{array}{l}\text { IST }\left({ }^{\circ} \mathrm{C}\right) \\
\text { CONTROL } \\
\text { CELL }\end{array}$ & $\begin{array}{l}\text { IST }\left({ }^{\circ} \mathrm{C}\right) \\
\text { GREEN FACADES } \\
\text { CELL }\end{array}$ & $\begin{array}{l}\text { IST }\left({ }^{\circ} \mathrm{C}\right) \\
\text { GREEN ROOF } \\
\text { CELL }\end{array}$ & $\begin{array}{l}\text { IST }\left({ }^{\circ} \mathrm{C}\right) \text { GREEN } \\
\text { FACADES+ GREEN } \\
\text { ROOF CELL }\end{array}$ \\
\hline$T^{\circ} \mathrm{C}$ Min. & 13,8 & 14,3 & 14,5 & 14,8 \\
\hline$T^{\circ} \mathrm{C}$ Max. & 25 & 22,2 & 24,1 & 24,1 \\
\hline$\triangle T^{\circ} \mathrm{C}$. & 11,2 & 7,9 & 9,6 & 9,3 \\
\hline
\end{tabular}




\subsubsection{Internal surface temperature's west wacades}

The West facades have the same behaviour as the North facades discussed above. In the early hours of the day, when the lowest daytime temperatures are recorded, the lowest internal surface temperature is registered in the test cell constructed with conventional materials.

The remaining test cells show almost the same temperature, to the moment when the external temperature begins to rise. The highest external temperature $\left(26^{\circ} \mathrm{C}\right)$ occurs at $14 \mathrm{~h}$, on the other hand, the two test cells with no vegetation on their West facades (Control cell with Green. roof), have the highest temperatures $\left(22.8^{\circ} \mathrm{C}\right)$ at $18 \mathrm{~h}$, that is, there is a difference about $3^{\circ} \mathrm{C}$ with respect to the external temperature and has a thermal delay of $4 h$.

Conversely, the lower temperatures are found in both cells with vegetation on their walls (Green facades cell and Green facades and Green roof cell) with $21.5^{\circ} \mathrm{C}$ at $18 \mathrm{~h}$, that is, with a difference of almost $5^{\circ} \mathrm{C}$ with the external temperature and a thermal delay of 4 hours.

Figure 13 shows the graph of the internal surface temperatures in West facades and external air temperature

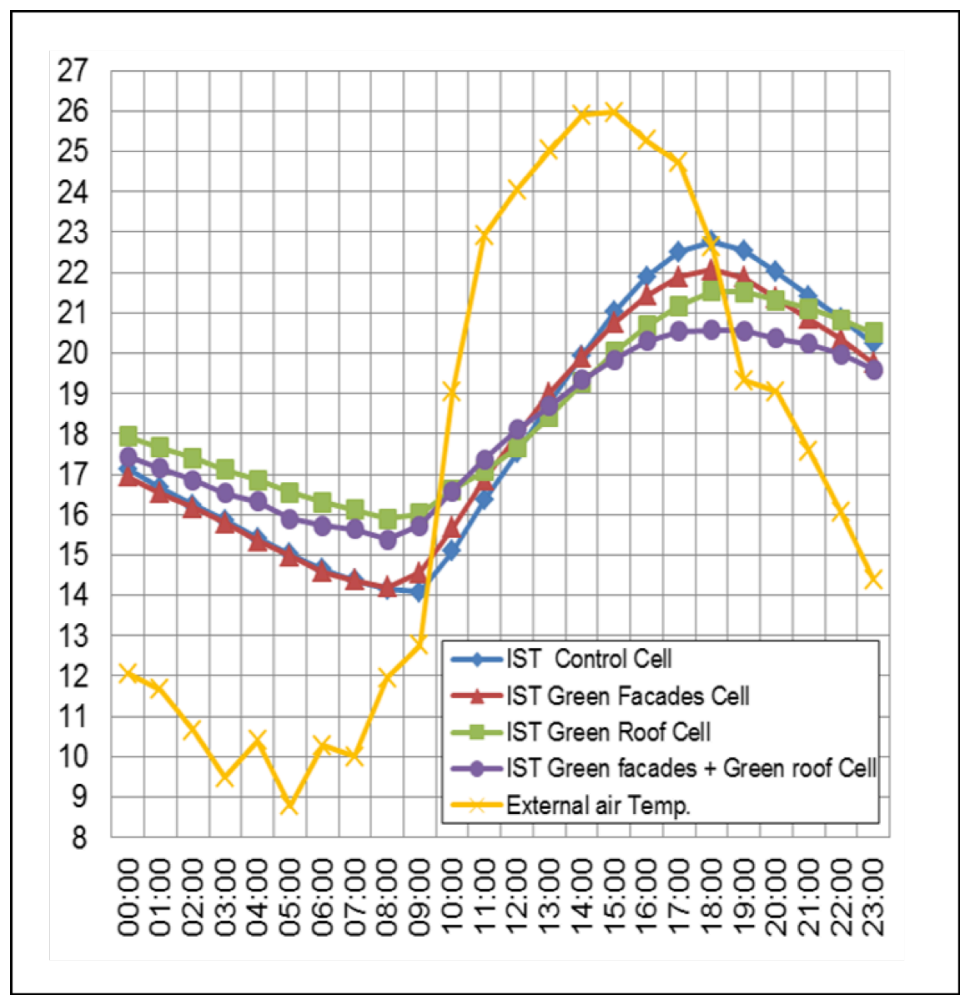

Figure 13. Internal surface temperature of west facades vs. external air temperature chart. Source: Own author Source: Own author.

In Table 5, the thermal amplitudes recorded in each test cells are described. There, it can be seen that the highest amplitudes are manifested in the Control cell $\left(9^{\circ} \mathrm{C}\right)$ (conventional materials) which has Green Roof $\left(8.2^{\circ} \mathrm{C}\right)$. Conversely, the lowest are observed in the cell constructed with Green facades and the Green roof cell (approx. $7^{\circ} \mathrm{C}$ ).

Table 5. Thermal amplitudes in west facades. Source: Own author

\begin{tabular}{|c|c|c|c|c|c|}
\hline WEST FACADES & $\begin{array}{l}\text { IST } \\
\text { CONTROL } \\
\text { CELL }\end{array}$ & $\begin{array}{l}\text { IST } \quad\left({ }^{\circ} \mathrm{C}\right) \text { GREEN } \\
\text { FACADES CELL }\end{array}$ & $\begin{array}{l}\text { IST }\left({ }^{\circ} \mathrm{C}\right) \text { GREEN } \\
\text { ROOF CELL }\end{array}$ & $\begin{array}{l}\left.\text { IST } \quad{ }^{\circ} \mathrm{C}\right) \\
\text { FACADES+ } \\
\text { ROOF CELL }\end{array}$ & $\begin{array}{l}\text { GREEN } \\
\text { GREEN }\end{array}$ \\
\hline$T^{\circ} \mathrm{C}$ Min. & 13,9 & 14,4 & 14,6 & 14,8 & \\
\hline$T^{\circ} \mathrm{C}$ Max. & 22,9 & 21,6 & 22,8 & 22,1 & \\
\hline$\Delta T^{\circ} C$ & 9 & 7,2 & 8,2 & 7,3 & \\
\hline
\end{tabular}




\subsubsection{Internal surface temperatures of roofs}

In Figure 14, the evolution of internal surface temperatures of the four roofs over the analysed period is represented.

During the first hours of the day and when the lowest internal and external temperatures are recorded, it is observed that the two cells with roofs constructed with ceramic tiles have the lowest internal surface temperatures. However, the two cells with vegetation on their roofs have the highest internal surface temperatures, although this difference in temperature does not exceed two degrees. Nevertheless, there is a difference of almost $8^{\circ} \mathrm{C}$ in the external temperature with respect of test cells equipped with vegetation on their roofs. Besides this, a thermal delay of three hours is also seen.
In the part of the day where the highest temperatures were recorded, corresponding to the period of the afternoon, the highest temperature is observed in the test cell constructed with conventional materials $\left(22.8^{\circ} \mathrm{C}\right.$ at $\left.18 \mathrm{~h}\right)$ followed by cell equipped with green facades $\left(22.1^{\circ} \mathrm{C}\right.$ at $\left.18 \mathrm{~h}\right)$. Conversely, the lowest temperature among the maximum is given in the test cell with Green roof and Green facades $\left(20.6^{\circ} \mathrm{C}\right.$ at $\left.19 \mathrm{~h}\right)$, followed by the cell with Green roof $\left(21.5^{\circ} \mathrm{C}\right.$ at $\left.19 \mathrm{~h}\right)$.

In the evening period, it is observed a thermal delay between cells built with vegetation on their roof of 4 hours, while cells constructed with ceramic tile roofs recorded a thermal delay of 3 hours.

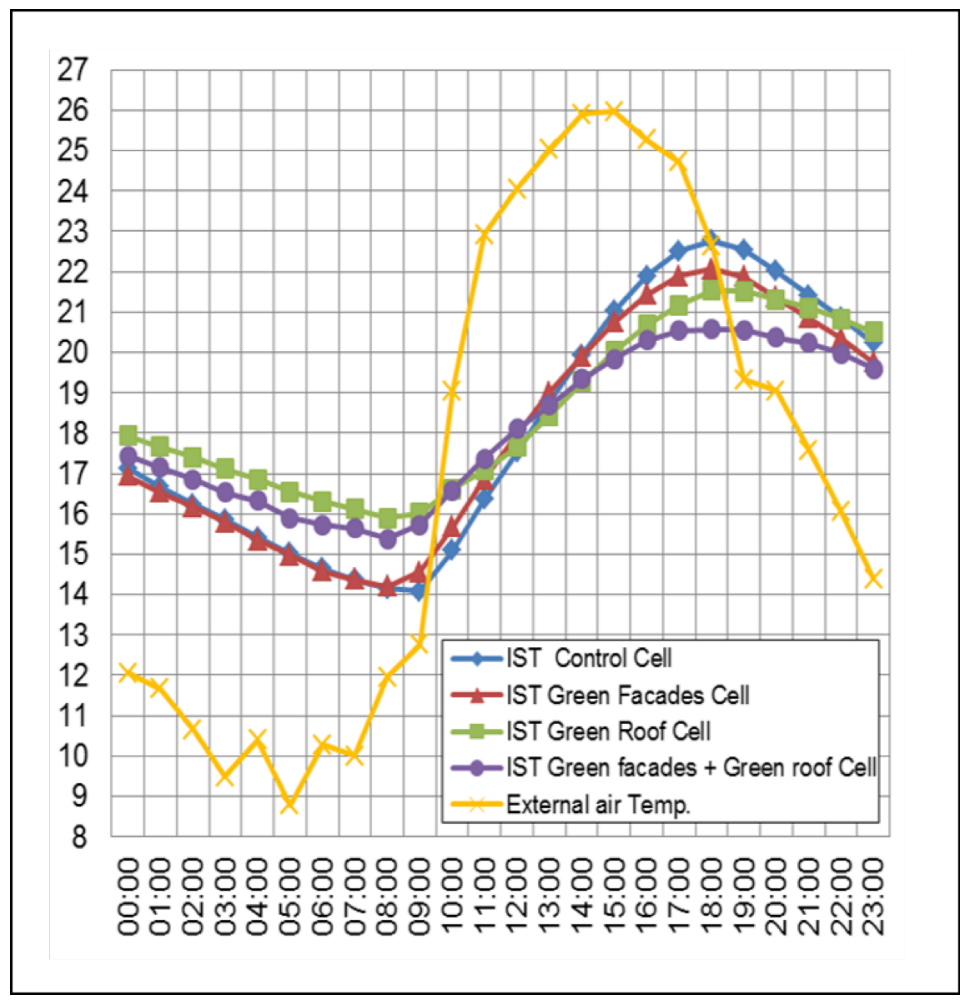

Figure 14. Internal surface temperature in roofs vs. external air temperature. Source: Own author

The lowest thermal amplitude have been recorded in the test cell covered by vegetation $\left(5^{\circ} \mathrm{C}\right)$, both in facades and roof, and the highest thermal amplitude $\left(8^{\circ} \mathrm{C}\right)$ was recorded in the Control cell, built with conventional materials. Then, Table 6 summarizes the indicated thermal amplitudes. 
Table 6. Summary table with thermal amplitudes in roofs

\begin{tabular}{|l|lc|l|l|l||}
\hline ROOFS & $\begin{array}{l}\text { IST } \\
\text { CONTROL } \\
\text { CELL }\end{array}$ & $\begin{array}{l}\left.{ }^{\circ} \mathrm{C}\right) \\
\left.\text { IST }{ }^{\circ} \mathrm{C}\right) \text { GREEN } \\
\text { FACADES CELL }\end{array}$ & $\begin{array}{l}\text { IST }\left(^{\circ} \mathrm{C}\right) \text { GREEN } \\
\text { ROOF CELL }\end{array}$ & $\begin{array}{l}\left.\text { IST }{ }^{\circ} \mathrm{C}\right) \\
\text { FACADES+ } \\
\text { ROOF CELL }\end{array}$ & $\begin{array}{l}\text { GREN } \\
\text { GREEN }\end{array}$ \\
\hline$T^{\circ} \mathrm{C}$ Min. & 14,1 & 14,2 & 15,9 & 15,4 \\
\hline$T^{\circ} \mathrm{C}$ Max. & 22,8 & 22,1 & 21,5 & 20,6 \\
\hline$\Delta T^{\circ} \mathrm{C}$. & 8,7 & 7,9 & 5,6 & 5,2 \\
\hline
\end{tabular}

\section{Conclusions}

Since the thermal behaviour study with use of vegetation in cold periods for tropical climate, it is concluded that vegetation can reduce internal temperatures variations. The internal temperature of the cell where it was set vegetation on their facades and roof, maintains a stable temperature in the indoor environment. In the early hours of the day, where lower external temperatures are recorded, higher internal temperatures are observed.

In periods when the highest external air temperatures are recorded, the test cell equipped with Green facades and roof show the lowest thermal amplitude, i.e., it has less difficulty in transferring heat to outside. The highest internal air temperatures are presented in the cell built to conventions and lower in cell having Green facades and Green roof, with a difference between them of $1^{\circ} \mathrm{C}$.

The internal surfaces temperatures of the areas with vegetation, both facades and roofs remain more resistant to daily temperature variations. The highest difference between the maximum internal surfaces temperatures recorded, occurred between the cell control's roof and the cell with Green facades and Green roof, with a value of $2.2^{\circ} \mathrm{C}$.

Therefore, with these results can be concluded that the use of vegetation in construction works during tropical winter, protects covers (roofs and facades) of possible heat loss, that is, vegetation acts as insulation. The results obtained show that cells provided with plant maintain their internal air temperature almost $2^{\circ} \mathrm{C}$ above the others cells in the coldest periods.

Finally, it can be noted that the use of vegetation in architecture is a viable technique with several possible uses for the kind of climate studied, that contributes, in addition, to environmental benefits, provides internal thermal benefits that can improve thermal comfort to the occupants.

\section{References}

ASHRAE 55 (2013), American Society of Heating, Refrigerating and Air-Conditioning Engineers, Determining Acceptable Thermal Conditions in occupant - Controlled naturally conditioned spaces

ABNT. NBR 15575 (2013), Brazilian association of technical standards. Desempenho térmico de edificações. Parte 1- Edifícios habitacionais de até cinco pavimentos.

Dunnett N., and Kingsbury N. (2008), Planting Green Roofs and Living Walls. Portland, OR: Timber Press.

Ferrari A. L. (2012), Variabilidade e tendência da temperatura e pluviosidade nos municípios de Pirassununga, Rio Claro, São Carlos e São Simão (SP): Estudo sobre mudança climática de curto prazo em escala local. Engineering School of São Carlos, University of São Paulo, São Carlos.

Goatley J. M., Malddox V. L., Watkins R. M. (1996), Growth regulation of bahiagrass (Paspalum notatum Fluegge) with imazaquin and AC 263,222. HortScience, v. 31, n. 31, p. 396-399. Consulted 06/10/2015

$<$ http://www.scielo.br/scielo.php?script=sci_nlinks\&ref=000088\&pid=S0100-8358200200030002000004\&/ng=en>

Kinzie P. A. (1973), Thermocouple Temperature measurement. New York. John Wiley and Son. Inc.

Kissmann K. G. (1997), Plantas infestantes e nocivas. 2.ed. São Paulo: BASF Brasilian. p. 679-684. Consulted 08/04/2015 $<h t t p: / / w w w . s c i e l o . b r / s c i e l o . p h p ? s c r i p t=s c i \_n l i n k s \& r e f=000077 \& p i d=S 0100-8358200300010002000004 \& / n g=e n>$

Lorenzi H., Souza H. M. (2000), Plantas daninhas do Brasil: terrestres, aquáticas, parasitas e tóxicas. Nova Odessa: Plantarum. 349 p. Consulted 18/06/2015 < http://www.scielo.br/scielo.php?script=sci_nlinks\&ref=000104\&pid=S0100-8358200200030002000012\&/ng=en>

Martinez E., Scoones C., Paladini E. (2002), Thunbergia laurifolia lindl. (acanthaceae) exotic climber cultivated in argentina. Multequina, vol.11, n.1, pp. 61-64 Mendoza. Consulted 7/08/2015< http://www.scielo.org.ar/scielo.php?pid=S1852$73292002000100004 \&$ script $=$ sci_abstract\&t/ng=en>

Monteiro C. A. F. (1967), A dinâmica climática e as chuvas do Estado de São Paulo: estudo geográfico sob a forma de Atlas. São Paulo: University of São Paulo, Institute of Geography. 
Pérez G. (2010), Medida experimental de la contribución de las cubiertas y fachadas verdes al ahorro energético en la edificación en España. Ensayos con arquitectura vegetada. Seguridad y medio ambiente. No 118. Consulted 23/01/2015 < https://www.fundacionmapfre.org/documentacion/publico/es/catalogo_imagenes/grupo.cmd?path=1059105>

Roriz, M.; Chvatal, K. M. S., Cavalcanti, F. S. (2009), Sistemas constructivos de baixa resistência térmica podem proporcionar mais conforto. In. X ENCAC and VI Elacac- National Meetings and Latin American Comfort in the built environment. 2009, Natal. Anais... X ENCAC and VI ELACAC. Consulted 09/07/2015 <

http://www.fau.usp.br/cursos/graduacao/arq_urbanismo/disciplinas/aut0276/Desempenho_Termico/Roriz_Chvatal_Cavalcanti_2009_Baixa _Resistencia_Termica.pdf>

Vecchia, F. A. S. (2005), Climatologia aplicada ao ambiente construído. Análise do clima, avaliação e prevenção do comportamento térmico de edifícios ocupados. Escola de Engenharia de São Carlos, University of São Paulo.

Vecchia, F. A. S. (1997), Clima e ambiente construido: Abordagem dinámico aplicado ao conforto humano, University of São Paulo, São Paulo. Vecchia, F. A. S. (2005), Cobertura verde leve (CVL): ensaio experimental. In. XIII ENCAC IV ELACAC. National Meetings and Latin American Comfort in the built environment. 2005. Anais... XIII ENCAC e IV ELACAC. 